\title{
The Unified Patent Court: Pros and Cons of Specialization - Is There a Light at the End of the Tunnel (Vision)?
}

\author{
Jens Schovsbo • Thomas Riis • \\ Clement Salung Petersen
}

Published online: 21 April 2015

(C) Max Planck Institute for Innovation and Competition, Munich 2015

Upon its entry into force, the EU "patent package"1 will introduce a European patent with unitary effect and the Unified Patent Court (UPC) as the new patent judiciary for enforcement of European patents with or without such unitary effect.

\footnotetext{
1 The EU "patent package" consists of the Agreement of 19 February 2013 on the Unified Patent Court (UPCA); Regulation (EU) No. 1257/2012 of the European Parliament and of the Council of 17 December 2012 implementing enhanced cooperation in the area of the creation of unitary patent protection; and Council Regulation (EU) No. 1260/2012 of 17 December 2012 implementing enhanced cooperation in the area of the creation of unitary patent protection with regard to the applicable translation requirement.
}

This editorial is partly based on our two papers: "The Unified Patent Court (UPC) in Action - How Will the Design of the UPC Affect Patent Law?" (16 June 2014) in Transitions in European Patent Law Influences of the Unitary Patent Package (Kluwer forthcoming (2015)), available at http://ssrn.com/ abstract=2450945; and "The Unified Patent Court (UPC), Compulsory Licensing and Competition Law" (29 August 2014), Nordiskt Immateriellt Rättsskydd (NIR), 4/2014, pp. 324-339, available at http://ssrn. $\mathrm{com} / \mathrm{abstract}=2489006$. These papers include background information and more developed arguments for the thoughts presented here. Jens Schovsbo has presented this research at the IP Speaker Series in Oxford on 5 March 2015 (where the title of this editorial was also used). We also draw the attention to Professor Hanns Ullrich's editorial in 46 IIC 1 (2015) doi:10.1007/s40319-015-0298-z, which describes the general framework for the coming European patent system and its courts (including national courts and the Boards of Appeal of the EPO), and which briefly touches upon some the points we deal with more closely in the following.

\section{J. Schovsbo $(\square)$}

Professor, dr. jur., PhD

Centre for Information and Innovation Law, University of Copenhagen, Copenhagen, Denmark

e-mail: jens.schovsbo@jur.ku.dk

\section{T. Riis}

Professor, dr. jur., PhD

Centre for Information and Innovation Law, University of Copenhagen, Copenhagen, Denmark

\section{S. Petersen}

Associate Professor, $\mathrm{PhD}$

Centre for Enterprise Liability, University of Copenhagen, Copenhagen, Denmark 
The UPC will become part of an increasingly complicated European patent system, which consists of layers of EU law, international law, and national law, and which has till now been controlled by well-established institutions: the European Patent Organisation (including the Boards of Appeal), the national patent offices, the European Court of Justice (CJEU), and the national courts. The UPC will have to find a working relationship with these institutions which at the same time recognizes and reflects the existing order and provides room for the UPC to establish itself as master of its own house. This will no doubt be a complicated exercise, which it will take many years to develop fully.

The UPC is likely to become a central policymaker in the future EU patent system, and because of its institutional design, the UPC will be biased towards certain policy aims that, if unchecked, may lead to doctrinal isolation and to an underuse and/or development of mechanisms that have traditionally been considered important. Below, we will elaborate on these points and show how the UPC could systematically seek to cover its blind spots.

Presently, the centre stage of the European patent system is taken by the European Patent Organisation with its European Patent Office (EPO). It is through the EPO that substantive patent law is currently being developed with limited judicial control because national courts can only decide on the validity of patents within their own jurisdiction. ${ }^{2}$ Consequently, case law from national courts has had limited impact on the practices of the EPO. Furthermore, except for cases involving free movement of goods and competition law issues, the CJEU has never had much of a say in patent law since EU law within this area is scarce. Consequently, the EPO today enjoys considerable autonomy. From a traditional constitutional perspective, the current European patent system is thus dominated by a strong executive arm with limited judicial control.

The UPC will have the ability to change that. The competence to overrule decisions of the EPO relating to patentability, etc. in cases concerning patent validity enables the UPC to undertake a watchdog function vis-à-vis the EPO. The institutional design of the UPC clearly supports such a function in respect of strict patent law issues: Firstly, all judges of the UPC will be or will become specialised in patent law. Secondly, actions for revocation of a European patent shall be brought before the Central Division of the Court of First Instance, and a counterclaim for such revocation in an infringement action may be referred from a Local/Regional Division to be decided by the Central Division. ${ }^{3}$ At least in the Central Division, judges are thus likely to become just as qualified as members sitting on the EPO Boards of Appeal. 4

\footnotetext{
${ }^{2}$ See Art. 22(4) of Council Regulation (EC) No. 44/2001 of 22 December 2000 on jurisdiction and the recognition and enforcement of judgments in civil and commercial matters (Brussels I Regulation); and Art. 24(4) of Regulation (EU) No. 1215/2012 of 12 December 2012 on jurisdiction and the recognition and enforcement of judgments in civil and commercial matters (Brussels I Regulation recast).

${ }^{3}$ See Art. 33 UPCA.

${ }^{4}$ A BoA normally consists of two to three technically qualified members and one to two legally qualified members, see EPC Art. 21. The Enlarged BoA normally consists of five legally and two technically qualified members, Art. 22(2).
} 
Furthermore, the institutional design provides the UPC with a high degree of autonomy. Since the rules of the UPCA are not subjected to national law and the UPCA is so very difficult to amend, ${ }^{5}$ the practical possibilities of legislative control are limited.

The autonomy of the UPC is further increased by placing the court outside the scope of competences of the existing national court systems in respect of issues on which the UPC has exclusive competence, and by the limited role that the CJEU is intended to play as regards substantive patent law.

Based on these considerations, it is very likely that the future European patent system will to a large extent be governed by the judges of the UPC.

It has often been reported that specialist courts tend to develop biases and decide cases differently when compared to generalist courts. In the field of patent law, this point has often been substantiated by reference to the US experience with the Court of Appeals for the Federal Circuit (CAFC). ${ }^{6}$ Even when measured by the yardstick of the CAFC, the UPC is very specialised in respect of the court's competence and the appointment of judges.

The UPC will comprise both legally qualified judges and technically qualified judges. In litigation relating to infringement and validity of European patents, the UPC will usually sit in a composition of both types of judges. All judges are appointed by the representatives of the contracting member states in the Administrative Committee on the basis of a list of the most suitable candidates established by the "patent judges and practitioners in patent litigation with the highest recognised competence" in the Advisory Committee. ${ }^{7}$ This appointment procedure, where the community of patent law experts plays a crucial role, is likely to favour the appointment of judges specialised in patent law and patent litigation.

The UPC will have an extremely specialised jurisdiction and its judges are likely to become highly specialised in patent law and patent litigation. At the same time, the technically qualified judges will provide the court with a pronounced technical perspective. In this way, the UPC will reflect the general patent community of highly specialised patent lawyers and patent agents with both legal and technical qualifications.

Because of its specialized nature, the UPC will be biased towards technologybased values. We expect that because of these biases the UPC will be rather reluctant to engage in analyses that involve broader, non-technical values such as those related to competition law analysis or ethical concerns. Even if such concerns were advanced by the parties, the UPC would arguably find it to be more difficult to deal with such issues compared to a traditional national court with broader competences and experiences. For these reasons, there is a risk that the patent law rules and principles that other courts have relied on to include non-technical values are going to be either overlooked or underdeveloped by the UPC.

Due to the often very complex technological issues underlying patent disputes, patent law is a natural subject for a specialised court and there is no reason to doubt

\footnotetext{
5 Article 87 UPCA.

6 See Clement Salung Petersen, Thomas Riis, and Jens Schovsbo, "The Unified Patent Court (UPC) in Action - How Will the Design of the UPC Affect Patent Law?" and the references therein.

7 See Arts. 12, 14 and 16 UPCA.
} 
that some benefits are gained by subjecting patent law to a specialized court. Firstly, it will promote institutional efficiency in the sense that the judges of the court are expected to develop expertise in patent law, which in turn should result in quicker adjudication. Secondly, it is expected to ensure doctrinal uniformity, and, normally, doctrinal uniformity is considered a positive feature of any legal order because it creates predictability. Thirdly, judges of a specialized court are expected to enhance legal accuracy, because they are expected to develop a superior understanding of the subject matter that will enable them to substantiate the judgments more precisely and in the end enhance the quality of the judgments. Arguably, this latter purpose has been paramount in the composition of the UPC court panels, since the panels are open for technically qualified judges and the UPCA requires that the legally qualified judges have proven knowledge of civil law and procedure relevant in patent litigation. ${ }^{8}$

In spite of the almost indisputable benefits of a specialised patent court, the optimal degree of specialization is unclear and the pertinent policy issue is then to establish at what degree of specialization the costs outweigh the benefits. Even though the design of the UPC has created an institutional bias towards technologybased values and interests, it remains to be seen to what extent and how the UPC's decisions actually will be affected by these biases, or whether the UPC will develop a balanced practice that is critical towards the EPO, takes into consideration nontechnological interests, and promotes diversity.

It is not our main point that such practices would necessarily be the better ones as seen from a general perspective. Our point is that such practices would not be necessarily unwanted, but that a development in such directions will be "uphill" and will require an effort by the UPC. If unchecked and unnoticed, there is a clear risk that the future EU patent system will lose some of the wiggling room and dynamics that have traditionally served it well. The first step towards a generally well-balanced, high-quality patent system is for the coming UPC judges to be aware of the biases embedded in the institutional design of the UPC.

More concretely, in order to deal with the institutional biases, we recommend that the UPC finds ways to systematically include values and interests lying in the court's blind spots. To counterbalance the strong focus on technology, the UPC should thus make sure that the judges also are trained in issues of a non-technical nature in an attempt to widen the focus to include other parts of law that are considered essential for the normal construction of legal order. In addition, the UPC should find ways to engage in a dialogue with interested circles and not just patent specialists. In the recruitment of legally qualified judges, it should be regarded as a particular strength for candidate judges to (also) have a broader (generalist) legal experience. To support legal creativity and the further dynamic development of substantive patent law, the UPC should recognize diversity amongst the judges and the various divisions of the court of first instance as a value. And in the same vein, the UPC should consider national experiences and practices as a pool of knowledge and utilize national experiences to identify common core concepts as best modes.

\footnotetext{
${ }^{8}$ Article 15 UPCA.
} 